\title{
THE VALUE OF COPYRIGHT LAW AS A DETERRENT TO DISCOVERY ABUSE
}

\section{AlAN LAWRENCE†}

In addressing discovery practices in mass tort litigation, ${ }^{1}$ courts and commentators tend to focus on the plaintiffs' discovery needs. The practice of sharing, or selling, discovered materials to other litigants is considered to be a means of promoting judicial economy and reducing discovery costs for both plaintiffs and defendants. Discovery sharing also encourages legal action by claimants who may have been unaware of the cause of their injury or discouraged from bringing suit by high litigation costs, of which discovery expenses form a substantial part. ${ }^{2}$

Discovery is a mutually educative process through which both sides obtain information necessary for building their own cases and for preparing a defense against the issues opposing counsel intends to raise. ${ }^{3}$ Avoiding the discovery process by securing the information from litigants in other suits may defeat the educative purpose of discovery and can actually reduce judicial efficiency and fairness by impairing the ability of opposing counsel to prepare effectively for trial. 4 In addition to the danger of being "sandbagged" at trial, the

† B.A. 1987, Tulane University; J.D. Candidate 1990, University of Pennsylvania.

1 Mass tort litigation refers to actions for personal injury that may involve a large number of plaintiffs and multiple defendants within a particular industry. See Weber, Mass Tort Litigation: The Pot Boils Over-Part One, 25 For the Def., Mar. 1983, at 12; see, e.g., In re Asbestos \& Asbestos Insulation Material Prods. Liab. Litig., 431 F. Supp. 906 (1977) (naming asbestos cases as an example of mass tort litigation). Although this Comment is confined to the area of products liability, the principles discussed apply to any litigation involving multiple claimants and the exchange of discovered material.

2 See infra notes 33-40 and accompanying text.

3 See Hickman v. Taylor, 329 U.S. 495, 501 (1947) (stating that discovery provisions should be interpreted as a device "to narrow and clarify the basic issues between the parties" and as a device "for ascertaining the facts ... relative to those issues"); Marcus, Myth and Reality in Protective Order Litigation, 69 Cornell L. Rev. 1, 6 (1983) (arguing that the intrusiveness of discovery is justified by the need for full preparation before trial); of. McGovern, Toward a Functional Approach for Managing Complex Litigation, 53 U. CHI. L. REv. 440, 445 (1986) (assessing increased litigation efficiency through judicial tools designed "to move the litigation pig through the judicial python").

4 See Kirsch, Evidence-sharing, Calif. Law., June 1985, at 19, 21-22 ("[W]hen the plaintiff's attorney fails to conduct discovery about serious issues because he's gotten 
exchange of discovered material among plaintiffs in different suits presents possibilities for injuring the products-liability defendant outside the courtroom. Discovered material may contain competitively sensitive information, the dissemination of which could financially harm the defendant-manufacturer in the marketplace.

Products-liability defendants traditionally have combatted the potential injury resulting from the dissemination of discovered materials through protective orders. For "good cause shown," a defendant-manufacturer can obtain a protective order that prevents the disclosure of commercial information in the court record and precludes the use of that information outside the specific case. ${ }^{5}$ Although a protective order would appear to resolve any problems presented by discovery sharing, this Comment will show that it does not offer the defendant adequate protection for trade secrets and sensitive commercial information.

The shortcomings of protective orders suggest the need for a means by which products liability defendants can maintain control over documents after litigation. Copyright is a mechanism that allows the defendant-manufacturer to control the dissemination of its technical materials without incurring the drawbacks associated with a protective order. Copyright protection is secured through the actions of the defendant rather than at the discretion of the court. ${ }^{6}$ If the plaintiff then reproduces or disseminates the protected materials without the defendant's permission, the defendant has a federal cause of action for copyright infringement. ${ }^{7}$ A successful infringement action yields actual or statutory damages and may result in an

it somewhere else, there's a danger of being sandbagged at trial because you're not ready to defend those issues." (quoting defense attorney Kevin J. Dunne)).

5 See FED. R. Grv. P. 26(c). Although products liability actions frequently are brought in state court, the federal rules governing discovery nevertheless are pertinent because a majority of states have adopted discovery rules similar to the federal rules. See F. James \& G. Hazard, Givil Procedure § 5.2, at 230 (3d ed. 1985).

6 Although unpublished works are accorded automatic copyright protection, a potential products liability defendant must take the initiative of registering any discoverable materials that qualify for copyright protection. See 17 U.S.C. $\$ \S 104(a)$, 408(a) (1982). Registration is a prerequisite to filing an infringement suit and to obtaining certain remedies such as statutory damages and attorney's fees. See id. at $\S \S 411,412$.

7 The exclusive rights provision of the Copyright Act confers upon the holder of a copyright the exclusive right "(1) to reproduce the copyrighted work in copies or phonorecords; (2) to prepare derivative works based upon the copyrighted work; (3) to distribute copies or phonorecords of the copyrighted work to the public by sale or other transfer of ownership, or by rental, lease, or lending ... "Id. at § 106; see also at $\S 501$ (b) (action for infringement of copyright). 
award of attorney's fees. ${ }^{8}$ The use of the Copyright Act also shifts the expense of protecting sensitive documents to the protected party. In securing a protective order, both parties incur costs from the expenses generated by both requesting and opposing the order in a court. ${ }^{9}$ By using copyright, the defendant-manufacturer absorbs all protection expenses, but at a significantly reduced cost. $^{10}$ Expenses imposed on the court are eliminated as well.

This Comment focuses on the practice of sharing discovery materials among plaintiff's attorneys, its tendency to subvert the discovery process, and its potential for abuse. The Comment examines protective orders as a means of containing discovery sharing, and suggests the utilization of the Copyright Act as an effective addition or alternative. Because of the limited subject matter of copyright protection, ${ }^{11}$ its use for products liability information will be prescribed only for technical documents, such as research and testing materials. This Comment does not propose a new form of copyright protection for discovered documents, but rather advocates its prophylactic use before litigation arises to protect sensitive technical information from unauthorized dissemination.

This Comment will describe the process for using copyright to contain discovery ${ }^{12}$ and, finally, will address the obstacles to its use in this manner. ${ }^{13}$ However, a sufficient governmental interest in protecting sensitive information during litigation exists to justify the

8 See id. at $\S \S 504$ (b) \& (c), 505.

9 Although stipulated orders may eliminate the initial litigation expense, both parties incur costs in formulating the stipulated order and in litigating a challenged stipulated order. See infra notes 102-05 and accompanying text.

10 The expenses involved in copyright registration are minimal. See D. Goldberg, Current Developments in Copyright Law 163 (1985). If infringement occurs, litigation expenses are incurred by both parties, just as both parties bear the costs of contempt proceedings for violation of a protective order. See infra note 111 and accompanying text. Under the Copyright Act, however, the defendantmanufacturer may recover these expenses if the infringement action is successful. See 17 U.S.C. $\$ 505$ (1982). Thus, copyright not only effectively shifts the costs of protecting information to the protected party, but also shifts the costs of improper disclosure to the disclosing party.

11 See 17 U.S.C. $\$ 102$ (1982).

12 See infra notes 125-62 and accompanying text.

13 See infra notes $163-99$ and accompanying text. The most significant obstacles are the "fair use" doctrine and first amendment concerns. The Copyright Act articulates the criteria for determining fair use; when examined in light of these criteria, discovery sharing will be shown not to constitute a fair use. Restriction of dissemination raises constitutional questions regardless of whether its source is a protective order or another device, such as copyright. See Seattle Times Co. v. Rhinehart, 467 U.S. 20, 36-37 (1984) (holding that if a "protective order is entered on a showing of good cause ...., [it] is limited to the context of pretrial civil discovery, 
resultant imposition upon the first amendment rights of litigants, which is an unavoidable side effect of both protective orders and copyright protection. ${ }^{14}$

\section{Discovery Sharing}

The practice of discovery sharing consists simply of one plaintiffs' attorney securing materials through the discovery process and sharing them with another plaintiffs' attorney involved in similar, subsequent litigation. Ordinarily, the defendant is identical in both cases. ${ }^{15}$ The materials may be provided without charge in a spirit of mutual assistance among members of the plaintiffs' bar, or the providing attorney may demand compensation. ${ }^{16}$ The informal exchange of research and advice among members of the plaintiffs' and defense bars is not new; the practice, however, has become more extensive and sophisticated recently. ${ }^{17}$ Discovery sharing originally accomplished through informal networking among plaintiffs' attor-

and does not restrict the dissemination of the information if gained from other sources, it does not offend the First Amendment').

14 See infra notes 101-12, 190-99 and accompanying text.

15 For example, in 1983, the Keene Corporation had approximately 10,000 pending cases and claims against it asserting liability for asbestos-related diseases. See Weber, supra note 1, at 13 (citing Keene Corp. v. Insurance Co. of N. Am., 667 F.2d 1034 (D.C. Cir. 1981), cert. denied, 455 U.S. 1007 (1982)).

16 In products liability actions, attorneys are most willing to share information when litigation against an allegedly defective product has emerged suddenly and unexpectedly. See Ranii, How the Plaintiffs' Bar Shares Its Information, Nat'l L.J., July 23, 1984, at 1, col. 3, 10, col. 1. If litigation against a particular product develops slowly with a limited number of attorneys at the forefront, those attorneys are less willing to share information with other attorneys who become involved at a later stage. See id.

The providing attorney may be compensated directly or through a contingency arrangement. Direct compensation generally occurs when the providing attorney assembles a packet of materials for which a flat fee is charged. See, e.g., Kehm v. Procter \& Gamble Mfg. Co., 580 F. Supp. 913 (N.D. Iowa 1983) (holding in contempt an attorney who, in violation of a protective order, sold packets of documents obtained through a Toxic Syndrome action against Procter and Gamble for a total of $\$ 67,618.10$ ), aff $d$, 724 F.2d 630 (8th Cir. 1984). Rather than a flat fee, the providing attorney may prefer a percentage of the other attorney's contingency fee. See Ranii, supra, at 10 , col. 1 (stating that providing attorneys have demanded $2 \%$ of an attorney's contingency fees for each case involving that product while also requiring a 33\% fee for referring cases). Selling information on a contingency basis raises an ethical question because of its relationship to referral fees. See id. This practice is considered unethical in any state that has adopted the provisions of either the ABA Model Code of Professional Responsibility or of the ABA Model Rules of Professional Conduct, both of which ban referral fees. See Model Rules of Professional Conduct Rule 7.2(c) (1987); Model Codes of Professional RESPONSIBILITY DR 2-103(B) (1981).

17 See Kirsch, supra note 4 , at 19. 
neys is now facilitated by formalized "litigation groups" or "clearinghouses." 18 Litigation groups collect materials concerning litigation against a specific product alleged to be defective. ${ }^{19}$ Typically, an attorney can take advantage of a litigation group's resources by paying a yearly membership fee that covers the administrative costs of the clearinghouse. Documents are then exchanged among members with copying and mailing costs as the only additional charges. ${ }^{20}$ Clearinghouses have existed since the 1962 formation of the MER/ 29 Group to coordinate litigation against Richardson-Merrell, Inc., the manufacturer of an anti-cholesterol drug alleged to cause cataracts. ${ }^{21}$

Just as with the MER/29 Group, the formation of a litigation group is "almost always prompted by the emergence of a new, esoteric and promising species of product liability."22 The clearinghouse also may hope to encourage litigation against a certain product. For example, Trial Lawyers for Public Justice organized the Airbag Clearinghouse as an information pool to fuel tort claims against automobile manufacturers that fail to equip their products with airbags. ${ }^{23}$

$18 \mathrm{See} i d$. at 20. Not only has the network become more extensive and formalized, but the range of materials has also expanded. In addition to discovery proceeds, the exchange also includes pleadings, legal research, expert witnesses, and evidence. See id.

19 Examples of product-specific litigation groups include the Asbestos Litigation Group, the Tobacco Liability Project, and various groups devoted to Dalkon Shield Litigation. See id.; O'Brien, Document Sharing Approved in Cigarette Cases, 119 N.J.L.J. 1140 (1987); Ranii, supra note 16, at 9, col. 1.

20 See Kirsch, supra note 4, at 20. In 1984, membership in the clearinghouse for formaldehyde cases cost $\$ 250$. See Ranii, supra note 16 , at 9, col. 1 .

Although the cost of membership may be nominal, participation in a clearinghouse involves monetary considerations other than savings on discovery proceedings. "The competition for leadership spots can be particularly intense because, in addition to professional prestige, money can be at stake. Litigation group leaders are in high-profile positions that tend to attract referrals." Id. at 10, col. 3 . These considerations may suggest a unique opportunity for abuse. An attorney may join a litigation group simply to gain exposure and attract referrals by running for a leadership position. The membership fee then takes on the character of a referral fee. See supra note 16.

21 See Kirsch, supra note 4, at 20; Ranii, supra note 16, at 9, col. 1. The model for the MER/29 Group was the informal exchange among lawyers representing victims of mass disasters. See id. at 9, col. 2; see also Rheingold, The MER/29 Story-An Instance of Successful Mass Disaster Litigation, 56 CALIF. L. REv. 116 (1968) (describing how plaintiffs' attorneys in the MER/29 litigation worked together voluntarily, without court intervention, to help dispose of over 1500 suits); Weber, supra note 1 , at 12 (describing some of the new discovery tactics used by lawyers in mass tort litigation).

22 Kirsch, supra note 4, at 20.

23 See id. Trial Lawyers for Public Justice is a "public interest law firm" located 
In addition to clearinghouses, individual practitioners continue to package and sell discovery materials for a flat fee. ${ }^{24}$ Information banks maintained by the organized plaintiffs' bar facilitate these sales. The American Trial Lawyers Association (ATLA) has organized the Products Liability/Medical Malpractice Exchange, ${ }^{25}$ a computerized information bank that provides research about a specific product or type of accident. ${ }^{26}$ A plaintiffs' attorney also may obtain a list of other attorneys who have contacted the ATLA Exchange with similar research requests. ${ }^{27}$ This list allows plaintiffs' attorneys to contact one another to exchange advice and trade discovery documents. Organizations such as the ATLA further facilitate the sharing and sale of discovery materials by publishing attorneys' requests for and offers of information on particular types of cases and litigation. ${ }^{28}$ The number of attorneys using national information banks ${ }^{29}$ and the existence of local exchanges ${ }^{30}$ demonstrate the important role the

in Washington D.C. See id. In 1985, the Airbag Clearinghouse made four volumes of materials available for $\$ 775$; use of the clearinghouse for a particular case costs $\$ 1,200$ plus five percent of any fee from a recovery. See id.

A litigation group may have as a purpose fomenting litigation against a particular product; this purpose may have the undesirable side effect of encouraging meritless claims by providing relatively inexpensive discovery materials. The availability of these materials increases the opportunity for the claimant to incorporate information that will add credibility to her claim and extract a settlement. The creation of such a clearinghouse may have this result, regardless of the original purpose: "[T]he group's birth is publicized in the general media and, consequently, 'injured people identify their rights to recover' damages they previously were unaware of." Ranii, supra note 16, at 10, col. 1 (quoting Detroit attorney J. Douglas Peters). A plaintiff with a legitimate grievance against a manufacturer, however, should not be deterred from bringing a lawsuit because of potential discovery cost, as she may be reimbursed. See infra note 40 .

24 See Kirsch, supra note 4, at 20 (commenting on a plaintiff' attorney who sold Dalkon Shield materials that included videotaped depositions of expert witnesses for $\$ 2,000$ for the initial case and $\$ 1,000$ for each following case).

25 See Larson, The Automated Exchange, Trial, Aug. 1987, at 83, 83.

26 See id. ("[I]t is now feasible for the researcher to send all the information available on only one manufacturer or even a particular model or type of accident."). Attorneys make requests by completing a form available in each issue of Trial, the ATLA's publication. See id. The fee varies according to the extent of the research, the 1987 average fee being $\$ 150$. See id.

27 See id.

28 See Kirsch, supra note 4, at 20.

29 See Larson, supra note 25, at 83 (noting that over 6,000 plaintiffs' lawyers use the ATLA Exchange annually).

30 The products liability information bank organized by the California Trial Lawyers Association (CTLA) is an example of a local exchange. See Kirsch, supra note 4 , at 20 . The CTLA also provides a listing of approximately 500 attorneys classified by the cases they have handled and produces a publication similar to that of the ATLA in which attorneys can publish requests for and offers of products liability information. See id. 
organized plaintiffs' bar plays in coordinating discovery sharing and indicate the prevalence of the practice.

The now pervasive practice of discovery sharing generally has been approved by the courts if no protective order has been issued. ${ }^{31}$ The courts permit this practice in an attempt to fulfill the requirement of Federal Rule of Civil Procedure 1 that the rules "be construed to secure the just, speedy, and inexpensive determination of every action."32 Discovery sharing is seen as a means of reducing discovery expenses for both the plaintiff and the defendant. ${ }^{33}$ Furthermore, the reduced role of the courts in various discovery proceedings conceivably promotes judicial economy. ${ }^{34}$

The desire to equalize the resources available to plaintiffs and defendants also favors the dissemination of discovered materials. The typical products liability suit pits an individual plaintiff who has retained a solo practitioner or an attorney from a small $\mathrm{firm}^{35}$ on a contingent fee basis ${ }^{36}$ against a large corporate defendant that has a working relationship with a large defense firm. ${ }^{37}$ The corporate

31 See, e.g., In re Halkin, 598 F.2d 176, 188 (D.C. Cir. 1979) (stating that discovery materials can be used by discovering party "for any purpose" in absence of a protective order); Patterson v. Ford Motor Co., 85 F.R.D. 152, 154 (W.D. Tex. 1980) ("There is nothing inherently culpable about sharing information obtained through discovery."); Williams v. Johnson \& Johnson, 50 F.R.D. 31,32 (S.D.N.Y. 1970) (" $[T]$ here is no merit to the all-encompassing contention that the fruits of discovery in one case are to be used in that case only.").

32 Fed. R. Crv. P. 1; see also Patterson, 85 F.R.D. at 153-54 (asserting that collaboration among plaintiffs' attorneys complies with the aims of Rule 1). Discovery sharing also furthers the purpose behind the federal rules and Hickman v. Taylor, 329 U.S. 495 (1947), and its progeny, of encouraging full disclosure of all information before trial. See Thames, Discovery Strategy, For THE DEF., Jan. 1986, at 12, 13 (citing Noteware, Discovery Abuse, 17 Forum 474, 475 (1982)). But see infra notes 52-87 and accompanying text (discussing discovery sharing's potential for abuse).

33 For the individual plaintiff, discovery sharing defrays the high costs associated with discovery proceedings. These expenses include the costs involved in the production and copying of documents, the analysis of any documents obtained, the deposition of defendants and third parties, the attorney supervision of all discovery proceedings, and the hiring of expert witnesses. See Note, Mass Products Liability Litigation: A Proposal for Dissemination of Discovered Material Covered by a Protective Order, 60 N.Y.U. L. REv. 1137, 1140 (1985). The defendant is spared the expense of producing documents to comply with multiple discovery requests. See id. at 1150 .

34 See Williams, 50 F.R.D. at 32 (suggesting that judicial time and effort would be saved if discovery sharing leads to the consolidation of cases).

35 See Ranii, supra note 16, at 9, col. 1 (observing that plaintiffs' firms often have only one or two attorneys and usually less than twenty).

36 See Note, supra note 33, at 1141 \& $\mathrm{n} .33$ (finding that plaintiff' attorneys generally work on a contingent fee basis for personal injury cases, which is calculated as a percentage of the total recovery after discovery and other costs are subtracted).

37 See Ranii, supra note 16 , at 9 , col. 1 . 
defendant apparently has an unfair advantage over the individual plaintiff. $^{38}$ The significant expense saved by discovery sharing may make economically feasible certain products liability actions requiring extensive discovery for individual plaintiffs ${ }^{39}$ and reduce the disparity between the plaintiff's and defendant's resources. ${ }^{40}$

A further merit of discovery sharing is its utility in detecting "stonewalling" tactics by the defendant. ${ }^{41}$ Knowledge of the types of documents that exist, if only from related litigation, allows plaintiffs' attorneys to pinpoint necessary materials and to counteract delay tactics or attempts to conceal documents by the defendant. ${ }^{42}$

\section{A. Containment of Discovery to the Pending Litigation}

Despite the advantages of discovery sharing, the practice conflicts with traditional views of the discovery process. The assumption that discovery is inappropriate if it is not in preparation for a pend-

38 Although a large defense firm retained by a large corporation will concededly have greater resources available, the power of an individual plaintiff raising a products liability action that implicates a defendant-manufacturer's principle product should not be underestimated:

An adverse jury verdict in a products case costs more to a manufacturer than the dollars he must pay to satisfy the judgment. Such a verdict can set the tone for future cases involving the same product and may lead to the demand that the product be redesigned or eliminated from manufacture altogether. And the attendant adverse publicity may cause a substantial drop in sales revenues from the manufacturer's remaining products.

Montgomery, Products Liability: Eliminating Discovery Excesses, FOR THE DEF., Oct. 1985, at 27, 27; see also Galanter, The Life and Times of the Big Six; or the Federal Courts since the Good Old Days, 1988 Wrs. L. Rev. 921, 952 (arguing that of the various social and economic factors, products liability litigation has the greatest effect on corporate policymaking). Therefore, although the cost of one lawsuit to a large corporate defendant may seem small in current dollar terms, the defendant cannot afford to take such a narrow view. An individual plaintiff bringing such a suit does have the power to command the respect of a corporate defendant.

39 See Wall St. J., Dec. 20, 1982, at 19, col. 4 ("'[B]uying evidence is the only way many plaintiffs can afford to gather evidence and reduce the cost of hiring expert witnesses ...").

40 This same result, however, is attainable without resorting to discovery sharing. The courts are free to exercise discretion in dividing costs among the parties or to order the defendant to bear all of the plaintiff's discovery costs. See Note, supra note 33, at 1141 \& n.30 (citing Discovery Proceedings in Federal Practice $\$ \S 4.23,5.21-.30$ (Shepard's ed. 1983); R. Haydock \& D. HerR, Discovery PRACTICE $\$ \S 1.7 .2-1.7 .3,3.3 .4$ (1982)).

41 See Ranii, supra note 16, at 9, col. 2

$42 \mathrm{See} i d$. If the actual documents have already been obtained through a discovery exchange, "stonewalling" by the defense is completely avoided. 
ing suit underlies discovery theory. ${ }^{43}$ The conventional expectations that discovery materials will not be revealed to the general public or disclosed to other litigants outside the specific action ${ }^{44}$ have been challenged. The Court of Appeals for the District of Columbia Circuit has concluded that "when a party obtains documents or information through the discovery process, he can 'use that information in any way which the law permits." "45

Contrary to the Halkin view, however, parties to litigation traditionally are believed not to have a right to disseminate discovered information to the general public ${ }^{46}$ or to other litigants. ${ }^{47}$ Several rationales justify limiting the use of discovered materials to the case

43 See Marcus, supra note 3, at 7. This assumption is so pervasive that it is rarely articulated. See id. at 7-8.

44 See id. at 55-57.

45 In re Halkin, 598 F.2d 176, 188 (D.C. Cir. 1979) (quoting Leonia Amusement Corp. v. Loew's, Inc., 18 F.R.D. 503, 508 (S.D.N.Y. 1955)). Other courts have followed the Halkin approach. See, e.g., National Polymer Prods., Inc. v. Borg-Warner Corp., 641 F.2d 418, 423 (6th Cir. 1981) (starting its analysis with the presumption that information obtained in discovery may be used for any purpose); Wilson v. Piper Aircraft Corp., 46 Or. App. 795, 799, 613 P.2d 104, 106 (1980) (warning that, without a protective order, discovery documents can be used without restriction). These courts incorrectly rely upon Leonia Amusement Corp. v. Loew's, Inc., 18 F.R.D. 503 (S.D.N.Y. 1955). See Marcus, supra note 3, at 55. In Leonia, the district court's denial of a protective order and determination that the plaintiff's attorney could use the discovered information in "any way which the law permits" was predicated upon the defendant's failure to show a bad faith intention on the part of the plaintiff's attorney to use the materials for collateral purposes. See Leonia, 18 F.R.D. at 508. The expansive language in Leonia is dependent upon a lack of evidence that the plaintiff's attorney intended to act in bad faith (use the discovered information outside the litigation) and, therefore, does not support the permissive use of discovery materials advocated by cases such as Halkin. See Marcus, supra note 3 , at 54-56.

46 See Rhinehart v. Seattle Times Co., 98 Wash. 2d 226, 235, 654 P.2d 673, 679 (1982), aff', 467 U.S. 20 (1983). The Supreme Court of Washington noted:

Nowhere in the history of the rules or in the commentaries which we have read upon them can we find any indication that the purposes included that of disseminating to the general public the information derived from discovery, or any suggestion that such dissemination would serve the ends sought to be achieved by the rule.

Id.

47 See Oppenheimer Fund, Inc. v. Sanders, 437 U.S. 340,353 n.17 (1978) (" $[W]$ hen the purpose of a discovery request is to gather information for use in proceedings other than the pending suit, discovery properly is denied ..."); Marcus, supra note 3 , at 56 ("[C]ourts often assert that using discovery for any purpose other than preparation for trial in the action in which the discovery is sought is bad faith that justifies denial of discovery."); see also Milsen Co. v. Southland Corp., 1972 Trade Cas. (CCH) I 73,865 (N.D. Ill. 1972) (holding that an attorney's statement that she planned to disclose discovery information to other plaintiffs was sufficient grounds for issuing a protective order). 
in which discovery is sought. Public disclosure of discovered materials discourages cooperation with discovery requests ${ }^{48}$ and infringes upon litigants' privacy interests, making discovery a more intrusive process than necessary. ${ }^{49}$ In products liability actions, fear of damaging publicity would encourage defendant-manufacturers to resist compliance with discovery requests. Moreover, the dissemination of discovered information among litigants may not be equitable, because each case requires different treatment of discovery, depending upon the extent to which issues are defined at the time of filing. ${ }^{50}$ An appropriate target of discovery in one case may not be a valid target in another, due to varying grounds for the denial of discovery available in each action..$^{51}$

\section{B. Discovery Sharing's Potential for Abuse}

\section{Unjust Enrichment for the Attorney}

English law has articulated an "implied undertaking" that material obtained through discovery cannot be disclosed. ${ }^{52}$ One of the justifications for the English law's implied rule suggests an additional reason to be concerned with the American practice of discovery sharing: the potential for unjust enrichment. ${ }^{53}$ British commentators have considered the possibility for discovery abuse, noting that "[i]f the implied undertaking were released as soon as the documents were read aloud in court, then a party (subject to the laws of copyright and defamation) would be free to sell their contents to the highest bidder."54 This same opportunity for direct and indirect monetary gain ${ }^{55}$ from discovery sharing in America raises similar concerns that the discovery process will be abused.

48 See Marcus, supra note 3 , at 56-57.

49 See id. at 57. 53.

50 See Ebersole, Discovery Problems: Is Help on the Way?, A.B.A. J., Jan. 1980, at 50,

51 See Marcus, supra note 3, at 56 (" $[\mathrm{I}] \mathrm{f}$ there is a ground for denial of disclosure in the other proceeding, it would be subverted if disclosure of the same information could be compelled in the first proceeding."). (1984).

52 See Eagles, Disclosure of Material Obtained on Discovery, 47 MoD. L. Rev. 284, 285

53 See id. at 296-97.

54 Id. at 296. This argument further contends that the courts have become a party to the act of expropriation by participating in the extraction of documents from the litigants. See id. at 296-97. The article suggests that in England, the actual sale of discovered documents by solicitors would constitute misconduct subject to disciplinary sanctions. See id. at 297.

55 Although the outright sale of discovered materials results in direct compensation, indirect gain is achieved through the expense saved by obtaining 
Excessive discovery ${ }^{56}$ is already a common abuse. ${ }^{57}$ Discovery sharing leads to a similar abuse of the discovery process. Overdiscovery is facilitated by the liberal scope of federal discovery provisions. ${ }^{58}$ The relevancy requirement of Rule $26(\mathrm{~b})(1)$ generally is satisfied if any possibility exists that the requested information might be relevant to the subject matter of the action; discovery will be considered irrelevant only when the targeted information has no potential bearing on the subject matter of the litigation. ${ }^{59}$ The lenient relevancy standard of the federal discovery provisions along with the increased opportunity for gain offered by discovery sharing are likely to encourage two forms of overdiscovery abuse: discovery in search of a cause of action and discovery as a means of gathering information for use in proceedings other than the pending suit. ${ }^{60}$

The ability to use discovered materials in other actions provides an increased incentive for the plaintiff in a products liability suit to embark on a "fishing expedition." 61 If a cause of action is found, it not only can be used in the pending suit, but can also be used in new

materials outside the discovery process. Even the offering of information free of charge in an informal exchange carries with it the expectation of future gain from a reciprocal offering. See infra note 72.

56 Excessive discovery or "overdiscovery" is "the use of discovery out of proportion to the matter at issue." Ebersole, supra note 50, at 51.

57 See FED. R. Crv. P. 26 advisory committee note (1983 Amendments) (observing that "the spirit of the rules is violated when advocates attempt to use discovery tools as tactical weapons rather than to expose the facts and illuminate the issues"); Ebersole, supra note 50, at 50 ("[T] he "average litigant is overdiscovered, overinterrogatoried, and overdeposed: as a result he is overcharged, overexpensed, and overwrought." " (quoting Judge Ruggero Aldisert of the Third Circuit)).

58 See FED. R. Crv. P. 26(b)(1) ("Parties may obtain discovery regarding any matter, not privileged, which is relevant to the subject matter involved in the pending action .... It is not ground for objection that the information sought will be inadmissible at the trial if the information sought appears reasonably calculated to lead to the discovery of admissible evidence."); see also Marrese v. American Academy of Orthopaedic Surgeons, 706 F.2d 1488, 1495 (7th Cir. 1983) (noting that "[t]he use of the liberal discovery provisions of the Federal Rules of Civil Procedure to harass opponents is common"), aff'd, 470 U.S. 373 (1985).

59 See Weber, Mass Tort Litigation: The Pot Boils Over - Part Two, For the Def., Apr., 1983, at 15 (citing United States v. I.B.M. Corp., 66 F.R.D. 215 (S.D.N.Y. 1974); LaChemise Lacoste v. Alligator Co., 60 F.R.D. 164, 171 (D. Del. 1973)) (noting that "discovery should ordinarily be allowed under the concept of relevancy unless it is clear that the information can have no possible bearing upon the subject matter of the action").

60 See United Presbyterian Church v. Reagan, 738 F.2d 1375 (D.C. Cir. 1984); Westmoreland v. CBS, Inc., 584 F. Supp. 1206 (D.D.C. 1984) (citing Oppenheimer Fund, Inc. v. Sanders, 437 U.S. 340 (1978)), aff'd in pertinent part and rev'd in part, 770 F.2d 1168 (D.C. Cir. 1985).

61 Presbyterian Church, 738 F.2d at 1383 (quoting United Presbyterian Church v. Reagan, 557 F. Supp. 61, 64 (D.D.C. 1982), affd, 738 F.2d 1375 (D.C. Cir. 1984)). 
actions against the same manufacturer implicating the same product. As courts move away from a negligence theory of products liability focusing on fault, towards a strict liability theory focusing on defect, ${ }^{62}$ the fishing expedition becomes more valuable. With the combination of strict liability and discovery sharing, any material obtained through discovery that suggests a defect in the product has the power to fuel not just a single action, but an entire series of lawsuits. This encourages a thorough dredging of the defendant's files in search of anything intimating an imperfection in a product. ${ }^{63}$

In addition to increasing the profit potential of exploratory discovery, the practice of discovery sharing presents an unnecessary temptation to gather information not for use in the pending suit, but in hopes that it might be of value to another plaintiff. Plaintiffs' attorneys may attempt to enlarge the scope of their discovery beyond what is required by the litigation at hand in order to collect information that can be exchanged with or sold to other plaintiffs' attorneys. ${ }^{64}$ The possibility of uncovering material that can be sold or exchanged may induce counsel to alter the course of litigation, rejecting settlement in order to attempt discovering potentially damaging information through the litigation process. ${ }^{65}$

\section{Use of Confidential Material as a Negotiating Tool}

Discovery beyond the bounds of the litigation is only the beginning of the potential for abuse nurtured by discovery sharing. Once information is obtained through discovery, the threat of its disclosure to other plaintiffs and to the general public provides the plaintiff with a "tactical edge" in settlement negotiations. ${ }^{66}$ The plaintiff can

62 See Montgomery, supra note 38, at 28; Berger, The Impact of Tort Law Development on Insurance: The Availability/Affordability Crisis and Its Potential Solutions, 37 AM. U.L. Rev. 285, 286 (1988).

63 See Montgomery, supra note 38, at 28-29 ("[T] is often faced with voluminous interrogatories and requests for production seeking that elusive memo from the junior executive in the Milwaukee branch thirty years ago, cautioning that six bolts instead of five should be used to provide greater safety.").

64 See Kirsch, supra note 4, at 22. Apparently, discovery-for-profit is not uncommon. One products liability defense attorney commented, "'Sometimes we'll get a case where the injuries are not serious and yet the plaintiff is spending huge amounts of money on discovery .... Then you suspect they're really trying to build a file to sell or share with other attorneys." "Id.

65 See Note, supra note 33, at 1154 (noting that some plaintiffs' atiorneys may not settle if they believe material obtainable through litigation has a monetary value).

66 See Kirsch, supra note 4, at 22, 86 (quoting Richards v. Superior Court, $86 \mathrm{Cal}$. App. 3d 265, 271, 150 Cal. Rptr. 77, 81 (1978)). In Richards, the court noted that 
use the threat of disclosure to pressure the defendant into a favorable settlement. ${ }^{67}$ The defendant's desire to avoid disclosure of certain information may be sufficiently strong that the plaintiff can effectively blackmail the defendant into a settlement agreement without having first obtained the information through discovery. In Marrese v. American Academy of Orthopaedic Surgeons, ${ }^{68}$ Judge Posner noted that "[d]iscovery of sensitive documents is sometimes sought not in a sincere effort to gather evidence for use in a lawsuit but in an effort to coerce the adverse party, regardless of the merits of the suit, to settle it in order not to have to disclose sensitive materials." 69

The threat of disclosure is made more ominous by the availability of advertising as a means for plaintiffs' attorneys to offer the discovered materials to potential plaintiffs. The Supreme Court's decision in Zauderer v. Office of Disciplinary Counsel ${ }^{70}$ indicates that the advertisement of discovered information is permissible and cannot be prohibited simply on the grounds that advertising will "stir up litigation."71

\section{Violation of Ethical Standards}

Although advertising the availability of discovered information is generally permissible, the sale of the materials is ethically questionable. ${ }^{72}$ The plaintiffs' bar contends that discovery sharing violates no standard governing professional conduct; ${ }^{73}$ however, both

"disclosure for purposes unrelated to the lawsuit" rarely serves any purpose other than being a weapon in settlement negotiations. See id.

67 See id.

68706 F.2d 1488 (7th Cir. 1983), affd, 470 U.S. 373 (1985).

69 Id. at 1495.

70471 U.S. 626, 631 (1985) (reviewing an attorney's placement of an advertisement offering to represent women injured by the use of the Dalkon Shield, stating that he was involved currently in other Dalkon Shield litigation).

71 Id. at 642. Although the advertising of discovered materials was indirect in Zauderer, the Court articulated the general proposition that advertising by attorneys cannot be restricted on the grounds that advertising will foment litigation unless the advertising is false or misleading. See id. at 643.

72 As stated before, English law condemns such sales. See supra notes 52-54 and accompanying text. American legal ethical standards indirectly challenge these sales as well. See supra note 16. Sharing discovered materials should trigger the same ethical considerations, because pooling is motivated by the expectation of future gain. Although the profit from an exchange of materials is not assigned a monetary value, attorneys who pool information realize a savings. Discovery sharing is not simply altruistic behavior on the part of the plaintiffs' bar, but is fueled in part by an expectation of a benefit (discovery at a reduced price) that can ultimately be assigned a monetary value. But see Kirsch, supra note 4 , at 19 (noting a statement by a plaintiffs' attorney that "[o]urs is a wonderful sharing profession").

73 See Kirsch, supra note 4 , at 86. 
the ABA Model Rules of Professional Conduct and the ABA Code of Professional Responsibility forbid an attorney's acquisition of a proprietary interest in the cause of action. ${ }^{74}$ When an attorney shares or sells discovery information, she essentially acquires a property interest in an aspect of the litigation. If the materials originally were obtained at the client's expense, the discovered information is the property of the client, not her counsel. ${ }^{75}$ The attorney's ability to profit from work product produced for a client, then, presents a potential conflict of interest. ${ }^{76}$ Without the client's permission, the attorney should not be free to disseminate materials obtained through discovery. ${ }^{77}$ In granting permission to share or sell discovered information, however, the client probably would not realize the value of the discovered materials. Because the attorney stands to profit through convincing a client to sell the dissemination rights for a low price, this situation presents a possible instance of diverging interests. ${ }^{78}$

Not only does discovery sharing have the inherent potential for conflicts of interest between the client in the original litigation and

74 Model Rules of Professional Conduct Rule 1.8(j) (1987); Model Code of Professional RESPONSIBILITY DR 5-103(A) (1981).

75 See Kirsch, supra note 4, at 86; Ranii, supra note 16, at 10, col. 2. The plaintiff pays for discovery indirectly, because discovery expenses are deducted from her recovery. It has been argued that the rule against obtaining a proprietary interest in the cause of action is not violated if the revenue from the sale of discovered information is used to offset the amount deducted from the plaintiff's recovery. See Note, supra note 33 , at $1155-56$. While this benefits the plaintiff by reducing the cost of discovery, the cost adjustment does not mean that the attorney has paid for discovery; the attorney has been reimbursed for the difference between discovery expenses and any revenue from the sale of the information.

76 See Kirsch, supra note 4, at 86 . For a discussion of the conflict posed by the sale of discovered material on a contingent fee basis, see supra note 16.

77 See Ranii, supra note 16, at 10, col. 2. This conflict is counteracted if the attorney devotes all profit received from the sale of discovered materials to defraying the client's discovery expenses. See supra note 75. If the proceeds from discovery sales exceed the client's discovery expenses, the problem of who is entitled to the profit remains. One line of argument claims that the profit should be used to compensate the attorney and original plaintiff for their efforts in obtaining and marketing the discovered information and for the additional benefit purchasers derive from having observed the usefulness of the information in securing a favorable settlement or judgment. See Note, supra note 33, at 1158. Another possibility is for attorneys actually to buy the rights to the discovered information from the client. See Darlin, Lawyers Who Won Verdicts in Rely Trials Are Selling their Evidence, Angering $P \notin \Xi G$, Wall St. J., Dec. 20, 1982, at 19, cols. 4, 6 (noting that attorneys paid client in Toxic Shock Syndrome claim against Procter and Gamble for the rights to discovered information in order to sell it for profit).

78 The attorney has both a monetary and a practice-enhancing interest, through increased referrals, to persuade the client to grant the attorney distribution rights to discovered materials. 
her attorney, but the practice may also prompt attorneys to behave. unethically in order to distribute the information. In Kehm v. Procter $\xi$ Gamble Manufacturing Co., ${ }^{79}$ an attorney who had earned between $\$ 80,000$ and $\$ 90,000^{80}$ by selling packets of materials obtained through a Toxic Shock Syndrome case against Procter and Gamble was held in contempt for including confidential documents covered by a protective order in the packets. ${ }^{81}$ Although the attorney claimed the documents were inadvertently included because of an error by a legal assistant who packaged the materials, ${ }^{82}$ the incident suggests that some attorneys might be willing to risk contempt sanctions in order to sell valuable materials covered by a protective order. ${ }^{83}$

The practice of discovery sharing has the potential to promote a variety of abuses on the part of the plaintiff and her attorney: overdiscovery, threatening disclosure as a tactical weapon, violation of ethical standards, and manipulation of judicial proceedings in order to make information available for dissemination. The practice may also stimulate abuses on the part of the defendant and, in cases of excess, casts a disreputable image of products liability litigation. ${ }^{84}$

79580 F. Supp. 913 (N.D. Iowa 1983), affd, 724 F.2d 630 (8th Cir. 1984).

80 See Ranii, supra note 16, at 10, col. 2.

81 See Kehm, 580 F. Supp. at 917.

82 See Ranii, Lawyer Cited in Document Sale, Nat'l L.J., July 18, 1983, at 10, cols. 2, 3.

83 The attorney was ordered either to retrieve the protected documents from the purchasing attorneys or secure agreements to be bound by the protective order. See id. The threat of a similar sanction is unlikely to be an effective deterrent of the intentional inclusion of protected materials in discovery packages sold to other attorneys. Rather than harming his reputation, the sanctioned attorney claimed that the proceeding actually provided positive publicity because accounts of the contempt ruling also reminded the public of the $\$ 300,000$ judgment he secured against Procter and Gamble. See id. at 10, col. 4.

Motions for summary judgment can be especially useful vehicles for the release of confidential materials into the public domain. An attorney who has secured confidential information through pre-trial discovery and seeks to be the first to introduce the materials into the marketplace has a strong incentive to file a meritless motion for summary judgment and import the confidential materials into the summary judgment proceedings. See Marcus, supra note 3, at $48-49$ (noting the "frequency and ease with which parties move for summary judgment, oftentimes as a pretext for public dissemination of discovery materials[;] a good faith rule provides inadequate protection").

84 To some, discovery sharing has the "sleazy" appearance of attorneys "selling evidence on the street corner." Darlin, supra note 77, at 19, cols. 4,6 . The practice results in such unlawyerly conduct as attempts to infiltrate litigation groups by defense attorneys and meetings of plaintiffs' attorneys kept secret in order to assure that no "mole" (defense attorney) will be present. See Ranii, supra note 16, at 10, col. 4 \& 11, col. 1. ATLA's curtailed involvement in litigation group activities, see id. 
The prospect that confidential materials will be disclosed publicly and that information obtained through discovery will be supplied to any plaintiffs' attorney who requests or purchases it may also encourage defendants to resist plaintiffs' discovery requests. ${ }^{85}$ Failure to comply with discovery requests is grounds for judicial sanctions, ${ }^{86}$ inducing defendants to attempt to immunize information from the discovery process. The systematic destruction of documents offers an attractive means of ensuring that materials will not be subject to discovery. ${ }^{87}$ That discovery sharing can instigate such practices as document shredding indicates that plaintiffs' interests might be better served by a system protective of a defendant's confidential information than by one permitting the free dissemination of discovered materials with the possible result that no evidence will remain to be discovered.

\section{Traditional Limitations On Discovery Sharing}

\section{A. Hickman v. Taylor}

Limiting the use of discovery materials to the particular case is consistent with the Supreme Court's interpretation of the discovery rules as expressed in Hickman $v$. Taylor. ${ }^{88}$ Containing the dissemination of discovered information serves the stated goal of the Hickman Court of obtaining "the fullest possible knowledge of the issues and facts before trial," 89 because the limitation assures that both the plaintiff and the defendant are aware of the information available to their opponent and, derivatively, the issues and facts upon which their opponent intends to focus. When plaintiffs resort to discovery

at 10 , col. 4, may signal a concern that discovery sharing is detrimental to the image of the plaintiffs' bar, indicating that there is a growing sense that the practice of disseminating discovered materials for profit is inappropriate. Cf. Darlin, supra note 77 , at 19 , col. 6 .

85 Cf. Marcus, supra note 3, at 21-22 (claiming that a decreased use of stipulated protective orders risks an increase in attempts to persuade courts to deny discovery altogether and the likelihood that defendants will not provide the requested information readily).

86 See FED. R. Civ. P. 37.

87 See Sackett, Lawyers Irate as Shredding Spreads Among Companies, L.A. Daily J., Sept. 21, 1987, at 1, col. 2; Cooper, Dalkon Document Destruction Disputed, Nat'l L.J., June 10, 1985, at 3, col. 1. Document shredding, however, has a legitimate purpose in the business setting as a means of preserving confidentiality. Also, valuable technical documents are unlikely to be destroyed.

88329 U.S. 495 (1947).

$89 \mathrm{Id}$. at 501 . 
sharing, they abrogate this mutually educative process and surprises can result at trial, pretrial, or settlement negotiations. ${ }^{90}$

Hickman's goal of full disclosure requires the active participation of both parties in discovery. The limitation of the use of discovered materials to the litigation in which they were secured not only complies with the traditional expectations of litigants, but also prevents surprise by a plaintiff who has obtained discovery outside the litigation and encourages the defendant's compliance with discovery requests. ${ }^{91}$ English jurists have recognized the benefits of containing discovery to the particular litigation as expressed in their common law "implied undertaking." 92

\section{B. Protective Orders}

Traditionally, protective orders have been the defendant's only shield against the loss of trade secrets through discovery sharing. To obtain a protective order, the defendant is completely dependent upon the discretion of the court. ${ }^{93}$ Furthermore, the court will tend to draw the protective order as narrowly as possible in order to avoid a first amendment conflict. ${ }^{94}$ The defendant, therefore, may be inadequately protected against discovery abuse, even if a protective order is in effect. Once in effect, protective orders are subject to modification or complete withdrawal by the courts, rendering them highly unreliable. ${ }^{95}$ In addition, should the plaintiff breach the protective

90 See Jemison, Discovery Problems Inherent in Products Cases, For the DeF., Feb. 1984, at 2, 2 (noting that defense attorneys could be disastrously unprepared if plaintiffs gain materials through information pools, not through discovery); Kirsch, supra note 4, at 22, 86 (referring to the threat of disclosure of discovered material as an added pressure in settlement negotiations).

91 See supra notes 43-44, 48 and accompanying text.

92 See Eagles, supra note 52, at 285 (citing Altersyke v. Scott, 1 All E.R. 469 (1948)).

93 See FED. R. Crv. P. 26(c) ("[T] he court ... may make any order which justice requires to protect a party or person from annoyance, embarrassment, oppression, or undue burden or expense ....").

94 See In re Upjohn Co. Antibiotic Cleocin Prods. Liab. Litig., 81 F.R.D. 482, 485-86 (1979), affd, 664 F.2d 114 (6th Cir. 1981).

95 See In re Agent Orange Prod. Liab. Litig., 99 F.R.D. 645, 650 (E.D.N.Y. 1983), affd, 818 F.2d 187 (2d Cir. 1987) (lifting a protective order in regard to all government documents because discovery taken from the government meant litigation was not primarily private in nature); Garcia v. Peeples, 734 S.W.2d 343, 348 (Tex. 1987) (holding a protective order overbroad for preventing the plaintiff from sharing information not only with similarity situated plaintiffs, but also with the defendant's competitors). 
order, the defendant's only recourse is a contempt proceeding. ${ }^{96}$ Obstacles to obtaining a protective order and their unreliability once secured, however, mean that protective orders too often are weak shields for sensitive commercial information and an inadequate means of combating the abuses that can result from discovery sharing. The court will only issue a protective order limiting the disclosure of discovered information if the defendant establishes that: (1) the information is a trade secret or other commercial information worthy of protection; (2) its disclosure would result in cognizable harm that merits protection; or (3) good cause for invoking the court's protection exists. ${ }^{97}$ Defendants rarely will be able to convince the court that requested information qualifies as a trade secret. ${ }^{98}$ Therefore, defendants must resort to the good cause standard in order to obtain protection. Courts have made the requisite showing of good cause to protect confidential documents as difficult to satisfy as the narrow definition of a trade secret, rendering protective orders virtually impossible to obtain in some jurisdictions. ${ }^{99}$ Courts have denied protective orders under the good cause standard

96 See Littlejohn v. Bic Corp., 851 F.2d 673, 683-86 (3d Cir. 1988); Quinter v. Volkswagen of Am., 676 F.2d 969, 970 (3d Cir. 1982).

97 Feldman, Protective Orders in Products Liability Cases, BrIEF, Fall 1984, at 38, 40 (citing Zenith Radio Corp. v. Matsushita Elec. Indus. Co., 529 F. Supp. 866, 889 (E.D. Pa. 1981); America v. Hooker Chemicals \& Plastics Corp., 90 F.R.D. 421, 425 (W.D.N.Y. 1981)).

98 See Barrett, Protective Orders Come Under Attack, Wall St. J., Aug. 31, 1988, at 27, cols. 3, 5 ('Judges are also looking more skeptically at manufacturers' contention that valuable trade secrets are frequently at risk in liability cases.").

The limited availability of trade secret protection is due to the narrow definition of a trade secret as a:

formula, pattern, device or compilation of information which is used in one's business, and which gives him an opportunity to obtain an advantage over competitors who do not know or use it .... [I]t is not simply information as to single or ephemeral events in the conduct of the business [such as] . . . the date fixed for the announcement of a new policy or for bringing out a new model ....

RESTATEMENT OF TORTS $\S 757$ comment b (1939).

In determining whether information sought through discovery is a trade secret, courts may consider:

(1) the extent to which the information is known outside of his business;

(2) the extent to which it is known by employees and others involved in his business; (3) the extent of measures taken by him to guard the secrecy of the information; (4) the value of the information to him and to his competitors; (5) the amount of effort or money expended by him in developing the information; (6) the ease or difficulty with which the information could be properly acquired or duplicated by others.

Id.

99 See Marcus, supra note 3, at 27. 
due to the defendant's inability to offer specific evidence that the disclosure of each document will cause definite damage and result in significant economic harm. ${ }^{100}$ The rigidity of the good cause standard is heightened by the court's conclusion in Halkin that the first amendment requires analysis of the order "on three criteria: the harm posed by dissemination must be substantial and serious; the restraining order must be narrowly drawn and precise; and there must be no alternative means of protecting the public interest which intrudes less directly on expression."101

The difficulty of securing a court-issued protective order usually is circumvented by the use of stipulated protective orders. ${ }^{102}$ A stipulated order relieves the parties of judicial proceedings and allows discovery to progress. The first amendment concerns expressed in the right of access cases, however, have imposed the same constraints upon stipulated orders as upon protective orders drafted by the court. ${ }^{103}$ Stipulated orders, therefore, are susceptible to modification or recision on first amendment grounds due to the absence of strict scrutiny and a specific factual showing, as demanded by Halkin, prior to the order's entry. ${ }^{104}$ The reduced utility of stipulated orders is not only the result of their unreliability in the face of first amendment challenges, but also the general sentiment among plaintiffs' attorneys that protective orders are undesirable. ${ }^{105}$

100 See, e.g., Smith v. Bic Corp., 121 F.R.D. 235, 242-43 (E.D. Pa. 1988) (denying a protective order to prevent disclosure of research on lighter design due to Bic's failure to provide specific evidence that it would suffer significant harm to its competitive and financial position), affd in part and rev'd in part, $869 \mathrm{~F} .2 \mathrm{~d} 194$ (3d Cir. 1989); United States v. Exxon Corp., 94 F.R.D. 250, 251 (D.D.C. 1981) (refusing to grant a protective order because Exxon did not show "how each document will cause ... f flagrant harm to Exxon's economic stature if released").

The requirement of a particularized showing of harm forces the defendant to educate the court on industry standards and operating procedures and the manner in which the sensitive information can be used by competitors. See Marcus, supra note 3, at 23. The education process inevitably results in the disclosure of a portion of the confidential material and provides the plaintiff with a "roadmap for using the confidential information." Id.

101 In re Halkin, 598 F.2d 176, 188 (D.C. Cir. 1979) (footnotes omitted); see also Marcus, supra note 3 , at 25 (stating that the introduction of a constitutional issue solidifies the emphasis on particularized findings of harm from disclosure).

102 See Marcus, supra note 3, at 2, 18. A stipulated order is an agreement between the two parties that conditions discovery upon preserving the confidentiality of sensitive materials and limiting discovery to the pending action. See id. at 9; Jemison, supra note 90 , at 3 .

103 See Marcus, supra note 3 , at 18.

104 See id. at 20.

105 This resistance is encouraged by commentators who strongly urge plaintiffs' attorneys not to agree to a protective order, or to challenge it immediately if it 
Once a protective order is actually obtained from the court, the order continues to be subject to uncertainty. On appeal, the protective order may be weakened or eliminated after discovery has occurred. ${ }^{106}$ Plaintiffs also may find tactical means to defeat the order $^{107}$ or simply ignore it. ${ }^{108}$ Noncompliance is a feasible alternative for plaintiffs because contempt sanctions do not always present a sufficiently threatening deterrent. ${ }^{109}$ Imposition of a fine is dependent upon evidence of a "clear and convincing" violation and a showing by the defendant that she suffered actual damages as a result of the violation of the protective order. ${ }^{110}$ Once the protective order has been violated, the defendant must return to court with adequate proof of a violation and resulting harm in order to obtain significant enforcement in a products liability suit. ${ }^{11}$

Finally, even an unchallenged, unviolated protective order may not serve the needs of a defendant-manufacturer. The desire of courts to comply stringently with the principle that "[a]ny protective order must be drawn as narrowly and precisely as possible in order to avoid infringement upon first amendment rights" 112 potentially

appears too restrictive, in order to avoid limitations on discovery and a possible waiver of the right to share discovered materials. See, e.g., Feldman, supra note 97, at 38; Riley \& Hoefer, Protective Orders: Machiavelli Would be Pleased, TRIAL, Nov. 1984, at $30,32$.

106 See, e.g., Cippollone v. Liggett Group, Inc., 106 F.R.D. 573, 586-87 (D.N.J. 1985) (modifying a protective order finding that the limitation of all information revealed through discovery to the pending litigation overstepped the bounds of Rule 26(c)); Garcia v. Peeples, 734 S.W.2d 343, 345, 348 (Tex. 1987) (holding a protective order issued by the trial court overbroad for barring discovery sharing with other plaintiffs).

107 See Riley \& Hoefer, supra note 105, at 34 (suggesting that plaintiffs' attorneys can share information despite limitations of protective orders restricting discovery to counsel in pending action by bringing other plaintiffs' attorneys into the case as cocounsel or consultants).

108 See supra note 83 and accompanying text.

109 See supra notes 82-83 and accompanying text.

110 See Quinter v. Volkswagen of Am., 676 F.2d 969, 975 (3d Cir. 1982). Relief granted in a contempt proceeding usually takes the form of a fine for the amount of damages inflicted by violation of the order and an award of costs and attorney's fees. See id.

111 In Quinter, the Court of Appeals held that the $\$ 10,000$ fine imposed by the district court for two instances of protective order violation was subject to reduction due to Volkswagen's inability to prove that one of the instances was a "clear and convincing" violation. See id. at 974-75; see also Littlejohn v. Bic Corp., 851 F.2d 673, 686 n.32 (3d Cir. 1988) (contempt motion dismissed due, in part, to lack of diligence in pursuing discovery on contempt issue).

112 In re Upjohn Co. Antibiotic Cleocin Prods., 81 F.R.D. 482, 486 (E.D. Mich. 1979), affd, 664 F.2d 114 (6th Cir. 1981). 
produces a protective order that is both an inadequate barrier to the dissemination of confidential information and unenforceable.

\section{Copyright As An Alternate Means Of Containing DisCOVERED INFORMATION}

The difficulty in obtaining protective orders and the inadequate protection they offer demand a legitimate mechanism by which defendants in products liability actions can control the dissemination of sensitive information without resorting to document destruction. Such a vehicle would encourage defendant compliance with discovery requests ${ }^{113}$ and reduce the potential for abuse on the part of plaintiffs' attorneys hoping to share valuable confidential information obtained through discovery. ${ }^{114}$ A recent products liability case suggests that copyright can provide a useful alternative or addition to protective orders in efforts to prevent the disclosure of sensitive commercial information. ${ }^{115}$

\section{A. Copyright Applied: Honda}

In Honda Research $\mathcal{F}^{2}$ Development Co. v. Loveall, ${ }^{16}$ the district court granted the request of Honda Research and Development Company (Honda R \& D) for a permanent injunction that restrained the defendant and his attorneys from disseminating certain materials obtained through discovery in a prior action against several divisions of Honda Motor Company (Honda). ${ }^{117}$ The documents that were the subject of the permanent injunction contained information regarding the design, specifications, safety testing, and component parts of an all-terrain vehicle manufactured by Honda, which was the target of a products liability suit. ${ }^{118}$ These documents had been copyrighted by Honda and the protection afforded by copyright law formed the basis for the district court's decision to issue the perma-

113 See supra notes $86-88,91$ and accompanying text.

114 See supra notes 53-87 and accompanying text.

115 See Barrett, Firms Use Copyright Law to Keep Documents Secret, Wall St. J., Aug. 31, 1988, at 27, col. 3 (discussing American Honda Motor Co.'s successful efforts to prevent dissemination of information discovered in prior litigation). See generally Jacobson, Protecting Discovery by Copyright, 15 J. Pat. \& Trademark. Off. Soc'y 483, 483-92 (1979) (discussing the use of copyright in the Honda case).

116687 F. Supp. 355 (E.D. Tenn. 1987).

117 See id. at 359.

118 See Loveall v. American Honda Motor Co., 694 S.W.2d 937, 938-39 (Tenn. 1985). 
nent injunction. ${ }^{119}$ The court reasoned that, as the "owner/author" of the copyrighted documents, Honda R \& D possessed the "exclusive right to do and to authorize certain enumerated acts, including the right to reproduce the copyrighted work in copies, to prepare derivative works, and to distribute copies of the copyrighted work to the public." 120 Noting that the owner of a copyright has the right to control the first public disclosure of the protected materials or to choose not to publish them at all, the court concluded that federal copyright law compelled enforcement of Honda R \& D's desire to withhold the disputed documents from public distribution. ${ }^{121}$

Honda $\mathrm{R} \& \mathrm{D}$ brought an action for injunctive relief because the attorneys for the plaintiff in the underlying products liability action stated an intent to distribute the copyrighted design and testing materials to attorneys "throughout the country who are or might be representing clients as plaintiffs in similar litigation against Honda Motors regarding defects in certain all-terrain vehicles." 122 In granting a permanent injunction, the court indicated that discovery sharing would constitute an infringement of Honda R \& D's rights under

119 See Honda, 687 F. Supp. at 359.

120 Id. (citing 17 U.S.C. $\$ 106$ (1982)); see also supra note 7 (quoting the exclusive rights provision of the Copyright Act).

121 See Honda, 687 F. Supp. at 359 (quoting Harper \& Row Publishers v. Nation Enters., 471 U.S. 539, 564 (1985)). The court had previously considered the protection required by federal copyright law in granting Honda $R$ \& D's previous request for a preliminary injunction preventing the dissemination of the same materials. See id. at 355-57 (granting a preliminary injunction). In issuing the preliminary injunction, the district court noted that the complete documents did not appear in any public record, including that of the United States Register of Copyrights; therefore, the failure to grant injunctive relief would have resulted in the exposure of the documents to Honda's competitors and "irreparable" harm. See id. at 357 .

Honda obtained special relief from the deposit requirement of 17 U.S.C. \$ 407(a) (1982 \& Supp. 1988) because the documents contained trade secrets. See Honda, 687 F. Supp. at 357; 17 U.S.C. $\$ 407$ (c) (1982) (giving Register of Copyrights power to "exempt any categories of material from the deposit requirements" by regulation). The Honda documents were exempted from the registration deposit requirement under the regulation for secure tests. See Honda, 687 F. Supp. at 357 (order granting preliminary injunction); see also infra note 147 (quoting the regulation that describes secured tests). This regulation only required that Honda deposit a limited portion of the sensitive materials accompanied by a summary of the contents of the complete documents. See Honda, 687 F. Supp. at 357 (granting a preliminary injunction). As a result of this relief from the deposit requirement, "complete copies of [the copyrighted documents were] nowhere to be found in any public record," convincing the court that the rights accorded the owner of a copyright demanded that dissemination of copyrighted materials by opposing counsel be enjoined. Id.

122 Honda, 687 F. Supp. at 359; see Answer and Motion to Dismiss at 5, Honda, 687 F. Supp. 355 (E.D. Tenn. 1987) (No. 3-85-1161) (admitting the attorney's desire to share documents with other plaintiffs' attorneys). 
copyright law. ${ }^{123}$ This suggests that copyrighting documents containing sensitive commercial information is an effective means of not only protecting valuable materials from exposure to competitors, but also combating the abuses encouraged by discovery sharing. ${ }^{124}$

\section{B. Amenability of Copyright to Protecting Discovery Materials}

Although used successfully in the Honda litigation, copyright is not a protection available to every type of document that products liability defendants seek to exclude from the discovery sharing process. The Copyright Act protects "original works of authorship fixed in any tangible medium of expression." 125 In order to receive copyright protection, any materials of a defendant-manufacturer must meet the threshold requirement of originality. ${ }^{126}$ This is not a stringent requirement; "original" in the context of copyright law simply means "independent creation." 127 Thus, research and testing materials satisfy the originality requirement unless copied from previous reports. These materials are subject to copyright under the protection afforded compilations of fact. ${ }^{128}$ Courts generally make

123 See Honda, 687 F. Supp. at 359.

124 In cases where distribution of discovery materials is used for legitimate ends, such as when plaintiffs have legitimate grievances and cannot obtain similar discovery results without unreasonable expenses or effort, a court could permit a plaintiff to secure the materials from a previous plaintiff without condoning violations of copyright. The court might allow the individual plaintiff to utilize the materials through the fair use exception to copyright violation. See infra notes 166-88 and accompanying text. Using copyright protection for documents thus allows needy plaintiffs to obtain discovery documents through sharing, but does not leave the decision to distribute the documents to the private bar. Rather than obtaining the materials from another plaintiff, a plaintiff who lacks resources may proceed with discovery and be reimbursed by the defendant at the court's discretion. See supra note 40 .

12517 U.S.C. § $102($ a) (1982).

126 See D. Goldberg, supra note 10 , at 18.

127 Id. at 19. The originality requirement simply acts as a prohibition against copying pre-existing materials. See id.; Denicola, Copyright in Collections of Facts: $A$ Theory for the Protection of Nonfiction Literary Works, 81 Colum. L. REv. 516, 521 (1981) (noting that a copyrighted work must exhibit some degree of creative intellectual effort, yet courts should not and do not attempt to define a requisite level of creativity); Patry, Copyright in Collections of Fact: A Reply, in D. Goldberg, supra note 10 , at 627, 635 (" $[\mathrm{I}] \mathrm{t}$ has become firmly established in the case law that the requirement of 'originality' does not refer to a desired modicum of artistic merit, but rather to the consideration that the work has been independently produced." (citing Alfred Bell \& Co. v. Catalda Fine Arts, Inc., 191 F.2d 99, $102-03$ (2d Cir. 1951))).

128 See 17 U.S.C. \& 103(a) (1982) (stating that the subject matter of copyright includes compilations); Denicola, supra note 127, at 527 ("Compilations of facts have long rested securely within the scope of copyright."). The Copyright Act defines 
the distinction that it is the arrangement of the data in the compilation that copyright protects, ${ }^{129}$ but another approach holds that the compilation process itself merits copyright protection. ${ }^{130}$ Under either rubric, product information is copyrightable because both the collection of facts and their arrangement are accomplished by the manufacturer. ${ }^{131}$

The facts that compose the content of the compilation are not protected by copyright. ${ }^{132}$ The Copyright Act's incorporation of the traditional distinction between the idea and its expression ${ }^{133}$ severely limits the protection actually provided by copyright. ${ }^{134}$ The exclusion of ideas such as procedures, processes, systems, and methods of operation from copyright protection ${ }^{135}$ reduces the value of

"compilation" as "a work formed by the collection and assembling of preexisting materials or of data that are selected, coordinated, or arranged in such a way that the resulting work as a whole constitutes an original work of authorship." 17 U.S.C. $\S 101$ (1982 \& Supp. 1988).

129 See Denicola, supra note 127, at 527 (citing Schroeder v. William Morrow \& Co., 566 F.2d 3 (7th Cir. 1977); Hartfield v. Peterson, 91 F.2d 998 (2d Cir. 1937); PIC Design Corp. v. Sterling Precision Corp., 231 F. Supp. 106 (S.D.N.Y. 1964)).

130 See id. at 528 ("The creativity or effort that engages the machinery of copyright, the effort that elicits judicial concern with unjust enrichment and disincentive, lies not in the arranging, but rather in the compiling. It is the effort of collecting that must be rewarded in order to preserve incentive and safeguard the author's investment of time and money, not the act of placing Abbott before Baker." (footnote omitted)). This approach is supported by infringement cases in which the court emphasizes the originality of the selection of data, rather than the arrangement. See id. at 530.

131 The originality of the collection and choice of facts is assured because the manufacturer has generated the factual data that forms the content of the compilation.

132 See Gottlieb \& Bochner, Copyrightability of Fact Works, in D. GoldBerG, supra note 10, at 522 ("Copyright protection does not extend to the facts or ideas underlying a work but only to the expression of those facts or ideas.").

133 See Denicola, supra note 127, at 523 (citing H.R. REP. No. 1476, 94th Cong., 2d Sess. 57, reprinted in 1976 U.S. Code Cong. \& Admin. News 5659, 5670; S. Rep. No. 473, 94th Cong., 1st Sess. 54 (1975)). Section 102(b) of the Copyright Act codifies the limitation: "In no case does copyright protection for an original work extend to any idea, procedure, process, system, method of operation, concept, principle, or discovery, regardless of the form in which it is described, explained, illustrated, or embodied in such work." 17 U.S.C. § 102(b) (1982). This exclusion leaves unprotected any tangible expression whose form is exclusively a function of its underlying ideas such as lists of ingredients or instructions. See Denicola, supra note 127 , at 522.

134 Copyright essentially protects the owner against copying. See Denicola, supra note 127, at 522. Protection of the ideas underlying the expressions that 17 U.S.C. \$ 102(b) (1982) excludes depends upon the law of patents and state trade secret laws. "[A] copyright protects the owner against copying, while a patent protects the owner against similarity." D. GoldBERG, supra note 10 , at 19.

135 See 17 U.S.C. § 102(b) (1982). 
copyright for a products liability defendant. As a manufacturer, the defendant will want most to shelter information regarding processes and procedures from exposure to competitors, disclosure to the general public, and dissemination to other plaintiffs' attorneys. Although copyright will prevent the unauthorized dissemination of the actual documents or other materials which express these concepts, ${ }^{136}$ plaintiffs' attorneys could circumvent the copyright protection by deposing witnesses who are capable of testifying as to the contents of the materials. The resulting deposition transcript would then be available for discovery sharing purposes. ${ }^{137}$

Despite the ability of plaintiffs' attorneys to avoid the copyright protection through the use of depositions, copyright law provides a valid barrier to the dissemination of discovered materials due to obstacles discouraging the use of the deposition tactic. The expense of depositions, the unavailability of witnesses, the improbability that witnesses will be able to recall accurately the contents of technical documents, and the greater evidentiary value of a copy of the original document all mitigate against the use of depositions to secure copyrighted materials for dissemination. ${ }^{138}$ Furthermore, since copyright protection is readily available, it is a viable means for preventing the exploitation of confidential materials. Testing and research documents, as unpublished works, receive automatic copyright protection. ${ }^{139}$ Although coverage of unpublished works is not dependent upon any action of the author, registration is a prerequisite to filing an infringement suit and the award of actual or statutory damages.and attorney's fees. ${ }^{140}$ Another inducement to register is

136 See 17 U.S.C. § 103 (1982); Denicola, supra note 127, at 523.

137 Other possible means of circumventing copyright protection include securing materials through discovery and disseminating information extracted from the documents or simply compiling lists of discovered materials for sale or sharing. In both of these scenarios, however, any subsequent plaintiff must still use the discovery process to obtain the actual documents.

138 Despite obtaining the information without directly copying the protected materials, copying from memory may nevertheless result in an infringement. See Franklin Mint Corp. v. National Wildlife Art Exch., 575 F.2d 62, 64 (3d Cir.), cert. denied, 439 U.S. 880 (1978).

139 See 17 U.S.C. $\$ 104$ (a) (1982) ("The works specified by sections 102 and 103 , while unpublished, are subject to protection without regard to the nationality or domicile of the author."). Section 104 extends to the documents of both United States and foreign manufacturers, enabling Honda, a Japanese corporation, to prohibit the dissemination of its confidential documents in the Honda case. See Brief and Memorandum of Law in Support of Plaintiff's Motion for Summary Judgment at 2-3, Honda Research \& Dev. Co. v. Loveall, 687 F. Supp. 355 (E.D. Tenn. 1987) (No. 3-85-1161) [hereinafter Brief in Support].

140 See 17 U.S.C. $\S \S 411$ (a), 412 (1982 \& Supp. VI 1988). 
that the certificate of registration constitutes prima facie evidence of the copyright's validity if challenged in a judicial proceeding. ${ }^{141}$

Registration requires the deposit of copies of the materials with the Copyright Office. ${ }^{142}$ For an unpublished work, only one copy must be filed. ${ }^{143}$ All deposited material is available for public inspection; ${ }^{144}$ therefore, the deposit requirement would seem to defeat the purposes behind copyrighting sensitive technical materials by subjecting the information to public access. ${ }^{145}$ A manufacturer registering confidential materials may, however, seek relief from the deposit requirement. The Register of Copyrights is authorized to grant special relief from the deposit requirement through regulatory standards. ${ }^{146}$ One such regulation is the special deposit provision for secure tests. ${ }^{147}$ This provision allows the manufacturer to submit one complete copy of the materials to be protected along with an identifying summary to the Library of Congress. Once the Copyright Office Examining Division determines the adequacy of the submitted matters, the Copyright Office retains a record of the deposit

141 See id. at $\$ 410(\mathrm{c})$.

142 See id. at $\S 408(a)$.

143 See id. at $\S 408$ (b).

144 See id. at $\S 705(\mathrm{~b})$.

145 See Comment, Protecting Trade Secrets Through Copyright, 1981 Duke L.J. 981, 997-98 (concluding that the use of copyright law to protect trade secrets is inadvisable because the deposit requirement results in public disclosure of confidential information). But see Warrington Assocs. v. Real-Time Eng'g Sys., 522 F. Supp. 367, 368 (N.D. III. 1981) (holding that copyrights do not mean necessarily that trade secrets have been disclosed or eliminate the "mantle of confidentiality").

146 See 17 U.S.C. $\$ 407$ (c) (1982) ("The Register of Copyrights may by regulation exempt any categories of material from the deposit requirements of [registration], or require deposit of only one copy or phonorecord with respect to any categories."). Section 408 (c)(1) provides:

The Register of Copyrights is authorized to specify by regulation the administrative classes into which works are to be placed for purposes of deposit and registration, and the nature of the copies or phonorecords to be deposited in the various classes specified. The regulations may require or permit, for particular classes, the deposit of identifying material instead of copies or phonorecords ....

Id. at $\S 408(\mathrm{c})(1)$.

147 See 37 C.F.R. $\$ 202.20$ (b)(4) (1988). The regulation states:

A "secure test" is a nonmarketed test administered under supervision at specified centers on specific dates, all copies of which are accounted for and either destroyed or returned to restricted locked storage following each administration. For these purposes a test is not marketed if copies are not sold but it is distributed and used in such a manner that ownership and control of copies remain with the test sponsor or publisher.

Id. 
and returns the sensitive materials to the manufacturer. ${ }^{148}$ The secure test regulation was upheld in National Conference of Bar Examiners v. Multistate Legal Studies, Inc. ${ }^{149}$ The court of appeals stated that the purpose of the deposit requirement is administrative, not the public disclosure of protected materials. ${ }^{150}$

Once the registration and deposit requirements have been satisfied, the manufacturer, as copyright owner, may prevent the dissemination of the copyrighted materials by instituting an infringement action. ${ }^{151}$ The exclusive rights provision of the Copyright Act assigns the owner the exclusive right to reproduce and distribute copies of the copyrighted materials, thereby providing the basis for an infringement action. ${ }^{152}$ The exclusive rights accorded the holder of a copyright include not only the right of first publication, but also the right not to publish in the first place. ${ }^{153}$ Although inclusion of protected materials in the court record constitutes "publication,"154 it does not preempt the exclusive rights of the copyright owner. ${ }^{155}$ In Douglas International Corp. v. Baker, ${ }^{156}$ the district court concluded that "the publication of previously copyrighted materials in court transcripts cannot possibly dedicate such material to the public."157 This decision indicates that dissemination of discovered copyrighted

148 See D. GoldBERG, supra note 10 , at 165 . This regulation provided Honda with special relief from the deposit of its testing and safety documents.

149692 F.2d 478 (7th Cir. 1982), cert. denied, 464 U.S. 814 (1983).

150 See id. at $486-87$. The court reasoned that:

[T] he Register of Copyrights under section 704(d) is required to preserve only a facsimile copy of 'all or any part' of a section 408 deposit, which may itself consist of only identifying materials. Thus whether the work is published or unpublished, the Copyright Act when viewed as a whole negates the notion that deposit requirements are for the purpose of delineating the scope of a copyright through public disclosure.

Id.

151 See 17 U.S.C. §501(a) \& (b) (1982).

152 See id. at $\S 106(1) \&(3)$.

153 See Harper \& Row Publishers v. Nation Enters., 471 U.S. 539, 564 (1985); see also Leon v. Pacific Tel. \& Tel. Co., 91 F.2d 484, 487 (9th Cir. 1937) (holding that the owner of a copyright may simply exercise the right to exclude others from using her property (citing Fox Film Corp. v. Doyal, 286 U.S. 123, 127 (1932))); Bicentennial Comm'n of Pa. v. Olde Bradford Co., 26 Pa. Commw. 636, 641, 365 A.2d 172, 176 (1976) (finding that a copyright may be exercised "in a purely proscriptive manner," preventing others from reproducing the protected work).

154 See National Polymer Prods. v. Borg-Warner Corp., 641 F.2d 418, 421 (6th Cir. 1981) (holding that the release of information during an open trial constitutes "publication").

155 See Brief in Support, supra note 139, at 8.

156335 F. Supp. 282 (S.D.N.Y. 1971).

157 Id. at 285. 
materials violates the exclusive rights accorded the owner of the copyright regardless of whether the materials were included in the transcripts of the proceedings. ${ }^{158}$

As in Honda, the defendant in a products liability action may prevent discovery sharing of copyrighted documents through preliminary and permanent injunctions. ${ }^{159}$ If injunctive relief is not obtained or the enjoined party refuses to comply, the Copyright Act provides additional remedies for the copying and distribution of copyrighted materials to facilitate discovery sharing. The defendantmanufacturer can recover the actual damages from infringement along with the profits earned by the plaintiffs' attorney from the sale or exchange of the copyrighted documents. ${ }^{160}$ Alternately, the manufacturer can avoid the difficulty of computing actual damages and the infringer's profits by opting for an award of statutory damages. ${ }^{161}$ In addition to actual or statutory damages, the court may

158 See Brief in Support, supra note 139, at 8; see also Plaintif's Response to Defendants' Motion to Dismiss at 4, Honda Research \& Dev. v. Loveall, 687 F. Supp. 355 (E.D. Tenn. 1987) (No. 3-85-1161) (asserting that "to permit defendants to freely disseminate [copyrighted] documents which they received as a result of civil litigation discovery would be to authorize defendants to publish documents owned by plaintiff and to which plaintiff has the right of publication or of nonpublication").

159 The Copyright Act provides that "[a]ny court having jurisdiction of a civil action arising under this title may ... grant temporary and final injunctions on such terms as it may deem reasonable to prevent or restrain infringement of a copyright." 17 U.S.C. $\$ 502$ (a) (1982). An injunction obtained under the copyright law can be served anywhere in the United States and is operable throughout the country. See id. at $\S 502(\mathrm{~b})$.

160 See id. at $\S 504$ (b). ("The copyright owner is entitled to recover the actual damages suffered by him or her as a result of the infringement, and any profits of the infringer that are attributable to the infringement and are not taken into account in computing the actual damages."). Unless the disseminating attorney sells the copyrighted materials for a fixed price, establishing her profits from infringement is very difficult. Although the attorney profits from the exchange of discovery information, assigning a monetary value to this benefit for the purposes of computing damages may be impossible. Even if sold at a fixed price, the inclusion of copyrighted materials in a discovery package with non-copyrighted documents would significantly complicate the computation of profits derived from infringement.

161 The statutory damages provision states that:

the copyright owner may elect, at any time before final judgment is rendered, to recover, instead of actual damages and profits, an award of statutory damages for all infringements involved in the action, with respect to any one work, for which any one infringer is liable ... in a sum of not less than $\$[500]$ or more than $\$[2] 0,000$ as the court considers just.

Id. at $\S 504(c)(1)$.

If the infringement is committed willfully, the court may increase the award to up to $\$ 100,000$. See id. at $\S 504$ (c)(2). 
award costs and attorney's fees to a manufacturer that prevails in an action for copyright infringement. ${ }^{162}$

\section{Constraints on the Use of Copyright to Contain Discovery Sharing}

Although copyright law is amenable to the prevention of discovery sharing, ${ }^{163}$ its use in this manner is vulnerable to attack as improper ${ }^{164}$, as well as an infringement upon the first amendment interests of plaintiffs and the general public. This criticism may stem from the traditional view that the purpose of copyright protection is to encourage the development of ideas by granting the author a monopoly over the expression of her ideas. ${ }^{165}$ While employing copyright to prevent the exchange or sale of discovery materials may constitute an atypical infringement action, the use of copyright in this manner is similar to copyright for factual compilations outside the context of litigation. Copyright as a barrier to discovery sharing promotes technological progress by assuring manufacturers that the documents embodying new developments will not be subject to unauthorized dissemination.

Copyright protection of discovery documents also could be rendered ineffective if a plaintiff claimed a fair use of the shared discovery materials. The fair use of copyrighted documents for purposes such as criticism or teaching acts as a limitation on the exclusive rights accorded the owner of a copyright. ${ }^{166}$ This exception raises the question of 'whether a court would allow plaintiffs' attorneys to share copyrighted materials obtained through discovery as a fair use. ${ }^{167}$ The district court in Honda rejected the argument that the

162 See id. at $\S 505$.

163 See Honda, 687 F. Supp. at 359 (using a permanent injunction effectively as a means of protecting copyrighted discovery materials).

164 See Barrett, supra note 115 , at 27, col. 4. The existence of a fair use exception may counteract the argument that discovery materials should not be copyrightable. See supra note 124.

165 See Sony Corp. of Am. v. Universal City Studios, Inc., 464 U.S. 417,429 (1984). The purpose of copyright is derived from the copyright clause, which grants Congress the power " $[\mathrm{t}] \mathrm{o}$ promote the Progress of Science and useful Arts, by securing for limited Times to Authors and Inventors the exclusive Right to their respective Writings and Discoveries." U.S. CoNST. art. I, § 8, cl. 8. For additional views on the purpose behind copyright, see Breyer, The Uneasy Case for Copyright: $A$ Study of Copyright in Books, Photocopies, and Computer Programs, 84 HaRv. L. Rev. 281, 291-94 (1970) (arguing that copyright protects the economic incentive for intellectual activity); Denicola, supra note 127, at 519 (contending that copyright protects the "natural right to the fruits of one's labor").

166 See 17 U.S.C. \& 107 (1982).

167 See Barrett, supra note 115, at 27, col. 4. 
dissemination of copyrighted documents to other potential plaintiffs is a fair use. ${ }^{168}$ The possibility, however, of different outcomes in other cases arises because the doctrine is a loosely-defined, "equitable rule of reason," presenting an issue of fact in each case. ${ }^{169}$ "[A]lthough there are specific criteria that courts are directed to apply [in determining whether fair use exists in a particular case], courts often apply these criteria inconsistently and incomprehensibly."170

The criteria articulated in the Copyright Act for determining whether the employment of copyrighted materials is a fair use focus on whether the use was commercial or educational, the nature of the copyright materials, the extent of the copying, and the market effect of the use. ${ }^{171}$ Discovery sharing, as a means of obtaining discovery materials at a reduced price, may be a commercial use. The Supreme Court has said that "commercial use of copyrighted material is "presumptively an unfair exploitation of the monopoly privilege that belongs to the owner of the copyright." "172 The commercial character of the practice remains regardless of whether materials are sold or exchanged free of charge; " $[t]$ he crux of the profit/nonprofit distinction is not whether the sole motive of the use is monetary gain but whether the user stands to profit from exploitation of the copyrighted material without paying the customary price." ${ }^{173}$ The recipi-

168 See generally Honda, 687 F. Supp. at 357 (rejecting the defendant's argument of a fair use exception by finding that "the public has no interest in [the] documents").

169 See H.R. ReP. No. 1476, 94th Cong., 2d Sess. 65-66, reprinted in 1976 U.S. Code Cong. \& Admin. News 5659, 5678-79.

170 Francione, Facing The Nation: The Standards for Copyright, Infringement, and Fair Use of Factual Works, 134 U. PA. L. Rev. 519, 543 (1986).

171 Specifically, the Copyright Act states:

In determining whether the use made of a work in any particular case is a fair use the factors to be considered shall include -

(1) the purpose and character of the use, including whether such use is of a commercial nature or is for nonprofit educational purposes;

(2) the nature of the copyrighted work;

(3) the amount and substantiality of the portion used in relation to the copyrighted work as a whole; and

(4) the effect of the use upon the potential market for or value of the copyrighted work.

17 U.S.C $\S 107$ (1982).

172 Harper \& Row Publishers v. Nation Enters., 471 U.S. 539, 562 (1985) (quoting Sony Corp. of Am. v. Universal City Studios, Inc., 464 U.S. 417, 451 (1984)).

173 Nation, 471 U.S. at 562 (citations omitted). As expressed in the statutory language, the noncommercial use of a copyrighted work carries with it the connotation of an educational purpose. See 17 U.S.C. § 107(1) (1982). Although 
ent of copyrighted discovery materials profits from their exploitation in settlement negotiations and judicial proceedings without obtaining the materials through the customary discovery channels.

The fair use defense may also be inapplicable to copyrighted materials distributed through discovery sharing because they are considered unpublished. ${ }^{174}$ The scope of fair use is narrower with respect to unpublished works due to the author's right to control the first publication of her work or not to publish at all. ${ }^{175}$ The alleged fair use of unpublished technical documents by plaintiffs' attorneys is precluded by the manufacturer's right of first publication. ${ }^{176}$ Another characteristic that describes the nature of copyrighted material is its availability to potential users. ${ }^{177}$ If copies are unavailable "through normal channels," its unauthorized reproduction is better justified. ${ }^{178}$ Unlike out of print works, ${ }^{179}$ copyrighted discovery materials are available to other plaintiffs through the same discovery proceedings that originally produced the documents for the party seeking to disseminate them. ${ }^{180}$

The third criterion to determine the fair use of copyrighted materials is the amount and substantiality of the expropriated por-

discovery sharing may be seen as educating plaintiffs and their attorneys, this is not the scholarly, instructive, or critical use envisioned by the exception. See H.R. REP. No. 1476, 94th Cong., 2d Sess. 65-66, reprinted in 1976 U.S. COdE Cong. \& ADmin NEws 5659, 5678-79. Should a court find that an exchange of copyrighted discovery materials constitutes a nonprofit use because the transfer was not a fixed-price sale, the educational component of nonprofit use would nevertheless be unfulfilled.

The standard for establishing that a noncommercial use is unfair requires proof that the use is harmful or would adversely affect the potential market for the copyrighted work. See Sony, 464 U.S. at 451 . The dissemination of commercially sensitive materials is both harmful to the defendant-manufacturer and would destroy the value of the copyrighted materials due to the likelihood of exposure to competitors.

On the other hand, copyright would not prevent a court from establishing a library of documents for similar products liability cases, allowing other plaintiffs access to these materials. This use would not be classified as commercial because no private attorney would profit.

174 See Nation, 471 U.S. at 564 (citing 3 M. Nimmer, Copyright § 13.05[A] (1984); Comment, The Stage of Publication as a "Fair Use "Factor: Harper \& Row Publishers, Inc., v. Nation Enterprises, 58 ST. JohN's L. Rev. 597, 613 (1984)).

175 See id. at 564.

176 See id.; supra note 153 and accompanying text.

177 See Encyclopaedia Britannica Educ. Corp. v. Crooks, 542 F. Supp. 1156, 1177 (W.D.N.Y. 1982) (referring to the Senate Report on the 1976 Copyright Act, S. REP. No. 473, 94th Cong., Ist Sess. 64 (1975)).

178 See id.

179 See id.

180 See Brief in Support, supra note 139, at 10-11. 
tion in relation to the copyrighted material as a whole. ${ }^{181}$ Copying of the entire copyrighted document precludes application of the fair use doctrine. ${ }^{182}$ Discovery sharing would almost always require the wholesale copying of protected documents or, at the very least, the copying of sensitive excerpts. Although the copied portion of the protected work may be proportionately small, the amount and substantiality criterion also includes a consideration of the qualitative value of the copied material. ${ }^{183}$

In Harper $\mathcal{G}^{2}$ Row Publishers v. Nation Enterprises, ${ }^{184}$ the Supreme Court held that the publication of excerpts that formed the "heart" of President Ford's unpublished memoirs did not constitute fair use despite the fact that the excerpts, in absolute terms, were only an insubstantial portion of the memoirs. ${ }^{185}$ Thus, an emphasis on the quality, as well as the quantity, of copied materials would preclude the dissemination of excerpts that form the "heart" of copyrighted research and testing documents.

Finally, a court faced with the question whether discovery sharing constitutes fair use must consider the effect of the practice on the marketability of the disseminated materials covered by copyright. ${ }^{186}$ This requires an inquiry into the effect on the potential market for the copyrighted materials if the challenged use were to become widespread. ${ }^{187}$ The widespread dissemination of protected materials through discovery sharing almost assures that copies of confidential technical documents will fall into the competitors' hands. The competition's possession of the protected technical materials, then, would diminish the market demand for the copyrighted materials. ${ }^{188}$ Thus, when discovery sharing of copyrighted documents is examined

181 See 17 U.S.C. § 107(3) (1982).

182 See Marcus v. Rowley, 695 F.2d 1171, 1176-77 (9th Cir. 1983); see also MCA, Inc. v. Wilson, 677 F.2d 180, 183 (2d Cir. 1981) (noting that the "[u]se of copyrighted material ... generally will not be considered reasonable if it extensively copies or paraphrases the original or bodily appropriates the research upon which the original was based").

183 See Harper \& Row Publishers v. Nation Enters., 471 U.S. 539, 565 (1985).

184471 U.S. 539 (1985).

185 See id. at 564-65, 569 .

186 See 17 U.S.C. $\$ 107(4)$ (1982).

187 See Nation, 471 U.S. at 568 (quoting Sony Corp. of Am. v. Universal City Studios, Inc., 464 U.S. 417,451 (1984)).

188 The evaluation of the harm to the market for copyrighted materials must take into account not only the market for the original work, but also the market for any derivative works. See id. The overall damage resulting from the dissemination of copyrighted discovery materials is therefore increased by the related harm to the market for works based upon those materials. See 17 U.S.C. $\$ 101$ (1982) (defining "derivative work" as "a work based upon one or more preexisting works, ... [ [or a] 
under the four criteria articulated in section 107, it becomes apparent that the practice is not a fair use.

The final obstacle to the use of copyright to prohibit discovery sharing involving copyrighted works is the first amendment claims of other plaintiffs and the general public. ${ }^{189}$ Protective orders must withstand a similar first amendment challenge. ${ }^{190}$ For instance, plaintiffs may assert that enforcing a manufacturer's exclusive rights in copyrighted materials to prevent their dissemination acts as a prior restraint, depriving potential plaintiffs and the general public of information about an allegedly defective product. ${ }^{191}$ The essentially private nature of discovery in civil litigation, however, effectively counters such an argument. ${ }^{192}$ Because discovery is not a formal public proceeding, the general dissemination of information obtained through discovery is not warranted on public interest grounds. ${ }^{193}$ Furthermore, the protection of confidential information disclosed through discovery furthers a substantial governmental interest unrelated to the suppression of free expression: the prevention of discovery abuse. ${ }^{194}$ In Seattle Times Co. v. Rhinehart, ${ }^{195}$ the Supreme Court held that the prevention of discovery abuse is a sufficient justification for the authorization of protective orders, and therefore, does not offend the first amendment. ${ }^{196}$ The same governmental interest in discouraging discovery abuse would allow the prohibition of discovery sharing that included copyrighted materials to withstand first amendment scrutiny.

The act of copyrighting a manufacturer's technical documents, even if aimed at preventing their dissemination through discovery sharing, may withstand any first amendment attack simply on the grounds that copyright itself does not interfere with first amendment rights. ${ }^{197}$ By protecting only the specific expression of ideas, copyright does not restrict access to the information contained in a manufacturer's testing and design materials. ${ }^{198}$ The use of copyright to

work consisting of editorial revisions, annotations, elaborations, or other modifications which, as a whole, represent an original work of authorship. . .").

189 See supra note 13.

190 See supra notes $94,101-04$ and accompanying text.

191 See National Polymer Prods. v. Borg-Warner Corp., 641 F.2d 418, 424 (6th

Cir. 1981) (holding that the enforcement of a protective order was a prior restraint).

192 See Marcus, supra note 3, at 62-63.

193 See id.

194 See Seattle Times Co. v. Rhinehart, 467 U.S. 20, 34-35 (1984).

195467 U.S. 20 (1984).

196 See id. at 37.

197 See Denicola, supra note 127 , at $540-41$.

198 See id. (discussing the protection of collected facts for nonfiction works). 
protect a manufacturer's technical materials is thus an effective means of preventing their unauthorized dissemination through discovery sharing, yet does not abridge first amendment values of free expression. The failure of practices such as discovery sharing to merit first amendment protection when including copyrighted materials is summarized by Professor Denicola: " $[t]$ he objectives of our constitutional commitment to free speech will not often require the freedom simply to repackage and resell another's contributions."199

\section{CoNCLUSION}

The potential for profit offered by discovery sharing encourages abuse of the discovery process. As the traditional means of preventing discovery abuse, protective orders are not always effective. The difficulty of obtaining a protective order and the possibility of its modification or rescission indicate the manufacturer's need for a more reliable way to prevent unethical use of commercially sensitive materials disclosed through discovery. Inadequate protection of confidential documents only serves to induce evasion on the part of products liability defendants by tactics such as document destruction. As demonstrated by Honda, ${ }^{200}$ copyright offers an additional mechanism for containing the dissemination of documents secured through discovery. This approach is made practical by the special relief from the registration deposit requirement available through application to the Register of Copyrights. This relief avoids the disclosure of sensitive materials by registration. Copyright protection also provides the products liability defendant with the advantages of a federal cause of action to prohibit dissemination and actual or statutory damages should protected materials be distributed without authorization. Although the possibility exists that a court would permit the dissemination of copyrighted materials obtained through discovery based upon a misinterpretation of the fair use doctrine, discovery sharing generally would not satisfy the four criteria defining fair use. The only legitimate limitation on the use of copyright to exclude materials from discovery sharing is the subject matter to which copyright protection may be extended.

199 Id. at 541 (footnote omitted). 1985).

200 Honda Research \& Dev. Co. v. Loveall, 687 F. Supp. 355, 357 (E.D. Tenn. 